\title{
Mir-338-3p Mediates Tnf-A-Induced Hepatic Insulin Resistance by Targeting PP4r1 to Regulate PP4 Expression
}

\author{
Lin Dou ${ }^{a}$ Shuyue Wang ${ }^{a, b}$ Libo Sun ${ }^{c}$ Xiuqing Huang ${ }^{a}$ Yang Zhang ${ }^{a}$ Tao Shen ${ }^{a}$ \\ Jun Guo ${ }^{a}$ Yong Man ${ }^{a}$ Weiqing Tang ${ }^{a}$ Jian $\mathrm{Li}^{\mathrm{a}}$
}

aThe MOH Key Laboratory of Geriatrics, Beijing Hospital, National Center of Gerontology, Beijing, ${ }^{b}$ Nation Engineering Laboratory for Druggable Gene and Protein Screening, Northeast Normal University, Changchun, 'Department of Hepatobiliary Surgery and You-An Liver Transplantation Center, Beijing You-An Hospital, Capital Medical University, Beijing, China

\section{Key Words}

miR-338-3p • Hepatic insulin resistance $\cdot$ PP4R1 - TNF- $\alpha$

\begin{abstract}
Objective: Insulin resistance is a critical factor contributing to the pathogenesis of type 2 diabetes and other metabolic diseases. Recent studies have indicated that miR-338-3p plays an important role in cancer. Here, we investigated whether miR-338-3p mediates tumour necrosis factor- $\alpha$ (TNF- $\alpha$ )-induced hepatic insulin resistance. Methods: The activation of the insulin signalling pathway and the level of glycogenesis were examined in the livers of the $\mathrm{db} /$ $\mathrm{db}$ and high fat diet (HFD)-fed mice and in HEP1-6 cells transfected with miR-338-3p mimic or inhibitor. Computational prediction of microRNA target, luciferase assay and Western blot were used to assess the miR-338-3p target. Chromatin immunoprecipitation (ChIP) assay was used to determine the transcriptional regulator of miR-338-3p. Results: miR-338-3p was down-regulated in the livers of the $\mathrm{db} / \mathrm{db}$, HFD-fed and TNF- $\alpha$-treated C57BL/6J mice, as well as in mouse HEP1- 6 hepatocytes treated with TNF- $\alpha$. Importantly, the down-regulation of miR-338-3p induced insulin resistance, as indicated by impaired glucose tolerance and insulin tolerance. Further research showed that the down-regulated miR-338-3p resulted in the impaired AKT/ glycogen synthase kinase 3 beta (GSK3 $\beta$ ) signalling pathway and glycogen synthesis. In contrast, hepatic over-expression of miR-338-3p rescued the TNF- $\alpha$-induced insulin resistance. Moreover, protein phosphatase 4 regulator subunit 1 (PP4R1) was identified as a direct target of miR-338-3p that mediated hepatic insulin signalling by regulating protein phosphatase 4 (PP4). Finally, we identified hepatic nuclear factor 4 alpha (HNF-4 $\alpha$ ) as the transcriptional regulator of miRNA-338-3p. Conclusions: Our studies provide novel insight into the critical role and molecular mechanism by which miR-338-3p is involved in TNF- $\alpha$ induced hepatic insulin resistance. miR-338-3p might mediate TNF- $\alpha$-induced hepatic insulin resistance by targeting PP4R1 to regulate PP4 expression.

\begin{tabular}{ll}
\hline Jian Li & MOH Key Laboratory of Geriatrics, Beijing Hospital, National Center of Gerontology, \\
& Beijing 100730 (China) \\
& Tel. +861058115048, Fax +861065237929, E-Mail lijian@bjhmoh.cn
\end{tabular}

\section{KARGER}




\section{Cellular Physiology Cell Physiol Biochem 2017;41:2419-2431 and Biochemistry Published online: May 02, $2017 \quad$\begin{tabular}{l|l} 
Do 2017 The Author(s) \\
www.karger.com/cpb
\end{tabular} \\ Dou et al.: Mir-338-3p Regulate the PI3K/AKT Pathway}

\section{Introduction}

Metabolic syndrome is a cluster of metabolically related abnormalities, such as visceral adiposity, dyslipidaemia, hyperglycaemia and hypertension. Hepatic insulin resistance is a critical cause of metabolic syndrome and type 2 diabetes [1-3]. Hepatic insulin resistance is defined as a diminished ability of the hepatocytes to respond to the action of insulin on glucose metabolism. Decreased glycogenesis is a hallmark of insulin resistance in hepatocytes $[4,5]$. TNF- $\alpha$ has been recognized as an important mediator of hepatic insulin resistance by impairing the activation of the insulin signalling pathway [6-10].

MicroRNAs (miRNAs) are a class of endogenous small, non-coding RNAs that act as post-transcriptional regulators. Mature miRNAs negatively regulate gene expression by base pairing to the 3' untranslated region (3'-UTR) of their target mRNAs [11]. miRNAs are associated with different biological processes, including cell proliferation, differentiation and apoptosis [12]. It has been reported that aberrant miRNA expression is associated with the pathogenesis of type 2 diabetes $[13,14]$. For example, miR-375 could regulate insulin secretion [15]. The expression of miR-103/107 was up-regulated in obese mice. Silencing of miR-103/107 led to improved hepatic glucose homeostasis and insulin sensitivity [16]. In addition, miR-29a negatively regulated the insulin signalling pathway by targeting the p85 $\alpha$ subunit of PI3K [17]. Moreover, increased miR-181a was found in insulin-resistant cultured hepatocytes and mouse livers, and in the serum of diabetic patients. Over-expression of miR181a decreased the expression and activity of SIRT1 and caused hepatic insulin resistance [18]. In a previous study, we found that miR-200s, miR-301a and miR-19a participated in hepatic insulin resistance induced by IL-6 in vitro [19-21].

miR-338-3p is located within intron 8 of the apoptosis-associated tyrosine kinase (AATK) gene [22]. Previous studies have shown that miR-338-3p is related to the pathogenesis of cancer [23-25]. miR-338-3p is an intronic miRNA, and it is expressed in neuronal tissues [26]. Several studies have reported that miR-338-3p is related to neuronal diseases and tumour. However, little is known about the role of miR-338-3p in metabolic disorders, particularly in the development of insulin resistance.

In this study, we investigated the function of miR-338-3p in hepatic insulin resistance, suggesting that miR-338-3p was down-regulated in hepatic insulin resistance models and mediated glycogenesis by regulating the AKT/GSK3 $\beta$ signalling pathway.

\section{Materials and Methods}

\section{Insulin resistance models}

To determine the changes in miR-338-3p expression in hepatic insulin resistance, we used three hepatic insulin resistance models, including db/db mice, HFD-fed mice and TNF-a-treated C57BL/6J mice.

$\mathrm{The} \mathrm{db} / \mathrm{db}$ mice were derived from the C57BL/6J strain. Age-matched C57BL/6J mice were used as control animals for the $\mathrm{db} / \mathrm{db}$ mice. Both $\mathrm{db} / \mathrm{db}$ mice $(\mathrm{n}=5)$ and $\mathrm{C} 57 \mathrm{BL} / 6 \mathrm{~J}$ mice $(\mathrm{n}=5)$ were fed a standard laboratory diet (containing $5 \%$ fat and $21 \%$ protein) (Hua fu Kang, Beijing, China) for 12 weeks.

To established a diet-induced obese model, 4-week-old C57BL/6J mice ( $\mathrm{n}=5)$ were fed a high-fat diet (HFD, containing $21 \%$ fat, $19.5 \%$ casein and $1.25 \%$ cholesterol) for 12 weeks. As a control, age-matched C57BL/6J mice $(n=5)$ were fed a standard laboratory diet for 12 weeks.

For chronic TNF-a exposure, 16-week-old male C57BL/6J mice $(n=5)$ were fed a standard laboratory diet and treated with $15 \mu \mathrm{g} / \mathrm{ml}$ TNF- $\alpha$ by Alzet osmotic pumps (Durect, Cupertino, CA, USA) for 14 days with an infusion rate of $0.5 \mu \mathrm{l} / \mathrm{h}$, as previously described. As a control, age-matched C57BL/6J mice (n=5) were treated with $0.9 \% \mathrm{NaCl}$ by Alzet osmotic pumps for 14 days with an infusion rate of $0.5 \mu \mathrm{l} / \mathrm{h}$.

After an $8 \mathrm{~h}$ fast, the mice were anaesthetized by intraperitoneal injection with sodium pentobarbital. Blood samples were collected by cardiac puncture and the livers were removed, weighed, and snap-frozen in liquid nitrogen. Serum TNF- $\alpha$ level was determined with an ELISA kit for TNF- $\alpha$ (Sigma-Aldrich, St. Louis, MO, USA). 


\section{Cellular Physiology Cell Physiol Biochem 2017;41:2419-2431 \begin{tabular}{ll|l} 
and Biochemistry & $\begin{array}{l}\text { DOI: 10.1159/000475912 } \\
\text { Publisned onIIne: IVay 02, } 2017\end{array}$ & $\begin{array}{l}\text { () } 2017 \text { The Author(s). Published by S. Karger AG, Basel } \\
\text { www.karger.com/cpb }\end{array}$ \\
\cline { 2 - 3 }
\end{tabular} \\ Dou et al.: Mir-338-3p Regulate the PI3K/AKT Pathway}

All the animal experiments conformed to the protocols approved by the Animal Use and Care Committee of Beijing Hospital and the Guide for Care and Use of Laboratory Animals (NIH Publication \#8523, revised1996).

\section{Injection of adenoviral vectors}

To determine the effects of miR-338-3p on the TNF-a-induced insulin resistance, 7 days after the implantation of the TNF-a pumps, the C57BL/6J mice were injected with the recombinant adenoviral vectors expressing miR-338-3p mimic (AD-338m, 12 mice) or a negative control (AD-NC, 12 mice) via the tail vein $\left(2 \times 10^{9}\right.$ plaque-forming unit/ $25 \mathrm{~g}$ body weight $)$.

Similarly, the recombinant adenoviral vectors expressing miR-338-3p inhibitor (AD-338i) or inhibitor negative control (AD-NCi) were injected into C57BL/6J mice (12 mice for each group) via the tail vein $\left(2 \times 10^{9}\right.$ plaque-forming unit/25 g body weight).

\section{GTT and ITT}

For the glucose tolerance test (GTT) and the insulin tolerance test (ITT), 5 days after the adenovirus injection, 12 mice (6 mice for each group) were intraperitoneally injected with glucose $(2 \mathrm{~g} / \mathrm{kg}$ of body weight) or insulin ( $0.5 \mathrm{U} / \mathrm{kg}$ of body weight), respectively, after fasting for 8 or $4 \mathrm{~h}$. Blood glucose levels were measured with a glucometer (ACCU-CHEK Advantage, Roche Diagnostics GmbH, Mannheim, Germany) at $0,15,30,45,60$ and $90 \mathrm{~min}$ after the injection with glucose or insulin. Three days after GTT and ITT, the mice were anaesthetized by intraperitoneal injection with sodium pentobarbital. Then, blood samples were collected by cardiac puncture, and the livers were removed, weighed, and snap-frozen in liquid nitrogen.

\section{Cell culture}

HEP1-6, a cell line from mouse hepatoma purchased from American Type Culture Collection, was cultured as described previously [21]. The HEP1-6 cells were cultured in DMEM containing 10\% (v/v) foetal bovine serum (HyClone, Logan, UT, USA), $80 \mu \mathrm{nits} / \mathrm{ml}$ penicillin and $0.1 \mathrm{mg} / \mathrm{ml}$ streptomycin (Life Technologies, Inc., Carlsbad, CA, USA) at $37^{\circ} \mathrm{C}$ in a humidified atmosphere with $5 \% \mathrm{CO}_{2}$. The cells were stimulated with $10 \mathrm{nM}$ insulin for $10 \mathrm{~min}$ before harvesting the protein sample.

\section{Transfection}

The sequence of the miR-338-3p mimic and inhibitor were as follows (5'-3'): miR-338-3p mimic sense, UCCAGCAUCAGUGAUUUUGUUG; miR-338-3p mimic antisense, ACAAAAUCACUGAUGCUGGAUU; miR-338$3 p$ inhibitor, CAACAAAAUCACUGAUGCUGGA. The miRNA oligos were purchased from GenePharm. The miR338-3p mimic and inhibitor or the miR-negative control oligos were transfected for $48 \mathrm{~h}$ by using Effectene transfection reagent (Qiagen, Duesseldorf, Germany) according to the manufacturer's protocol.

\section{RNA isolation and real time PCR}

Total RNA of cells and livers was extracted by using TRIzol (Invitrogen, Carlsbad, CA, USA). Real time quantitative PCR was performed using the IQ5 detection system (Bio-Rad, Hercules, CA, USA) and SYBR Green Real time PCR Master Mix (Applied Biosystems, Foster City, CA, USA). The PCR primers are listed below (5'3'): miR-338-3p forward, GCGTCCAGCATCAGTGATT; miR-338-5p forward, GCGCAACAATATCCTGGTGC; U6 forward, GCGCTCGTGAAGCGTTC; universal primer, GTGCAGGGTCCGAGGT; 18s forward, GGAAGGGCACCACC AGGAGT; 18s reverse, TGCAGCCCCGGACATCTAAG.

\section{Western blot analysis}

Total protein $(20-30 \mu \mathrm{g})$ was subjected to $10 \%$ SDS-PAGE and transferred to a polyvinylidene fluoride (PVDF) membrane. The membranes were blocked with 8\% non-fat milk before incubating with 1:1000 dilution of specific primary antibodies at $4{ }^{\circ} \mathrm{C}$ overnight. After five washes in TBST (Tris-buffered saline containing $0.1 \%$ Tween 20 ), the membranes were incubated with 1:5000 dilution of horseradish peroxidase conjugated secondary antibodies in TBST for $1 \mathrm{~h}$. Bands were detected by chemiluminescence detection reagents (Millipore, Darmstadt, Germany). The antibodies against PP4R1, PP4, AKT, phosphorylation of AKT (ser473), GSK3 $\beta$, phosphorylation of GSK3 $\beta$ (ser9) and GAPDH were purchased from Cell Signalling Technology (Cell Signalling Technology, Danvers, MA, USA). 


\section{Cellular Physiology Cell Physiol Biochem 2017;41:2419-2431 \begin{tabular}{l|l} 
DOI: 10.1159/000475912 & O 2017 The Autho/ $(2)$ \\
www.karger.com/cpb
\end{tabular} \\ Dou et al.: Mir-338-3p Regulate the PI3K/AKT Pathway}

Measurement of glycogen content

The glycogen content of hepatocytes and liver tissues were measured by using a glycogen assay kit (BioVision, San Francisco, CA, USA) according to the manufacturer's instruction. Before the measurement, the HEP1-6 cells were stimulated with $10 \mathrm{nmol} / \mathrm{l}$ insulin (USBio, Swampscott, MA, USA) for $3 \mathrm{~h}$. The glycogen content of the liver was normalized by the tissue weight. In addition, the glycogen content of the cell was normalized by the amount of protein.

\section{Luciferase reporter assay}

The binding site of miR-338-3p on the 3'-UTR of PP4R1 was analysed by miRNA target prediction database, including miRanda, TargetScan and PicTar. The fragment of PP4R1 3'-UTR containing a putative binding site of miR-338-3p was cloned from mouse liver cells using the following primers:

\section{PP4R1-F-Sac I, TCGAGCTCGCTTTGCAAGCATTCACCCCT}

PP4R1-R-Xba l, GCTCTAGAGCAGACACAGTTGCACCTCAGA

A luciferase assay was used to assess whether miR-338-3p can directly bind to the PP4R1 3'-UTR. The amplified fragment of PP4R1 3'-UTR was inserted into the pmiRGLO vector (pmiRGLO-PP4R1). Five thousand cells per well in $100 \mu \mathrm{l}$ of medium were seeded in 96-well plates. The HEP1-6 cells were cotransfected with the pmiRGLO vector, pmiRGLO-PP4R1 and a miR-338-3p mimic (or negative control) using Effectene (Qiagen, Hilden, North Rhine-Westphalia, Germany) for 48 h. Luciferase reporter assays were performed by using the Dual-Glo Luciferase assay system (Promega, Madison, WI).

\section{Chromatin immunoprecipitation (ChIP)}

The Chromatin Immunoprecipitation Assay Kit was purchased from Millipore (Boston, Massachusetts, USA). According to the manufacturer's protocol, the nuclei extracted from the cells was sonicated into 2001000 bp fragments. Precleared chromatin was incubated with anti-HNF-4 $\alpha$ and control IgG antibodies overnight at $4^{\circ} \mathrm{C}$. Immunocomplexes were added with $50 \mu \mathrm{l}$ of protein $\mathrm{A} / \mathrm{G}$-Sepharose beads for $1 \mathrm{~h}$ and were washed four times. The precipitated DNA was purified with QIAquick (Qiagen, Duesseldorf, Germany) PCR purification columns and amplified with AATK-specific primers. The primers specific to the HNF- $4 \alpha$ binding sites on the AATK promoter were as followed:

HNF- $4 \alpha$ forward-1, GTCACTGACTTCGTGGTGGT;

HNF- $4 \alpha$ reverse- 1 , CCTTCCACCATCCGCTACTC;

HNF- $4 \alpha$ forward-2, TGTGGGCATCTCAAGAGGTC;

HNF- $4 \alpha$ reverse-2, ATTTCCTTCCACCATCCGCT.

\section{Statistical analysis}

Data were expressed as the mean \pm SEM. Statistical significance of differences between groups was determined by one-way ANOVA. $p<0.05$ was considered as statistically significant.

\section{Results}

miR-338-3p is down-regulated in the livers of $d b / d b$ mice, HFD-fed mice and TNF- $\alpha$ treated mice and in mouse HEP1-6 hepatocytes treated with TNF- $\alpha$

To profile the changes in microRNA expression in hepatic insulin resistance, miRNA microarrays were used to analyse miRNAs in the livers of $\mathrm{db} / \mathrm{db}(\mathrm{n}=5)$ and control mice $(\mathrm{n}=5)$. The results showed that miR-338-3p was down-regulated in the livers of the $\mathrm{db} / \mathrm{db}$ mice. Consistently, real-time PCR verified the reduction of miR-338-3p expression in the livers of the $\mathrm{db} / \mathrm{db}$ and HFD-fed mice (Fig. 1A, B). TNF- $\alpha$ has been implicated in the pathogenesis of insulin resistance. To assess whether TNF- $\alpha$ is involved in the down-regulation of miR-338$3 \mathrm{p}$ in hepatocytes, 12-week-old, male C57BL/6J mice were injected with $15 \mu \mathrm{g} / \mathrm{ml}$ TNF- $\alpha$ by pumps for 14 days. As shown in Fig. 1C, TNF- $\alpha$ injection led to a decrease in miR-338-3p expression in the mouse livers. Similarly, the glycogen content (Fig. 1D) and the activation of the AKT/GSK pathway (Fig. 1E) were reduced in HEP1-6 cells treated with $10 \mathrm{ng} / \mathrm{ml}$ TNF- $\alpha$ for $24 \mathrm{~h}$. 


\section{Cellular Physiology Cell Physiol Biochem 2017;41:2419-2431 \begin{tabular}{ll|l} 
aOI: 10.1159/000475912 & $\begin{array}{l}\text { ( ) 2017 The Author(s). Published by S. Karger AG, Basel } \\
\text { www.karger.com/cpb }\end{array}$ \\
\hline
\end{tabular}

Fig. 1. miR-338-3p is downregulated in the livers of $\mathrm{db} /$ $\mathrm{db}$ mice, HFD-fed mice and TNF- $\alpha$-treated mice and in mouse HEP1-6 hepatocytes treated with TNF- $\alpha$. Reduced miR-338-3p level in the livers of $d b / d b$ mice (A), HFDfed mice (B) and C57BL/6 J mice injected with $15 \mu \mathrm{g} /$ ml TNF- $\alpha$ by pumps for 14 days (C). Reduced glycogen content (D) and activation of the AKT/GSK3 $\beta$ pathway (E) in the HEP1-6 cells treated with $10 \mathrm{ng} / \mathrm{ml}$ TNF- $\alpha$ for 24 h. The expression of miR338-5p was not changed in the livers of TNF- $\alpha$-treated mice (F). Importantly, the expression of miR-338-3p also significantly decreased in human NAFLD patients

(A)

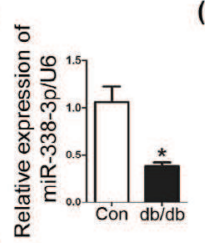

(E)
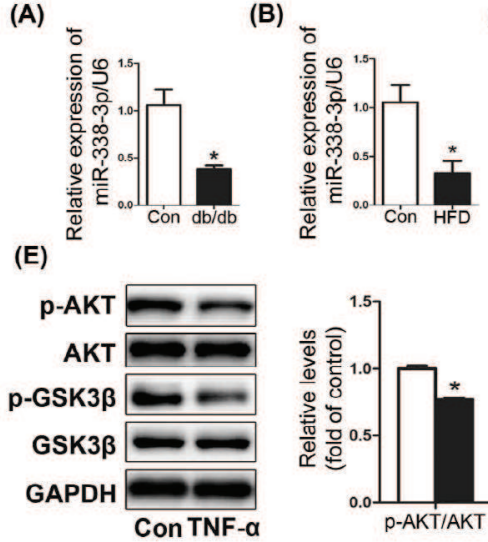

(C)
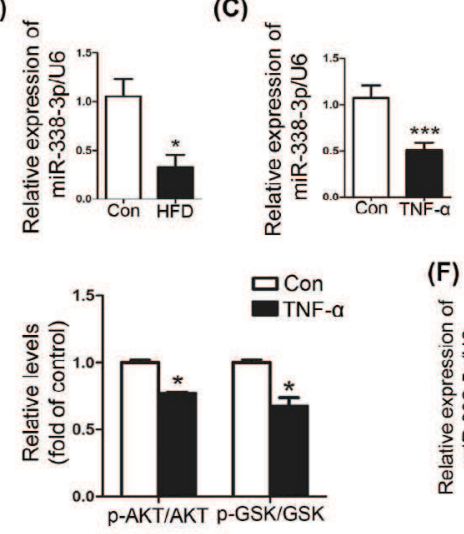

(D)

(G)

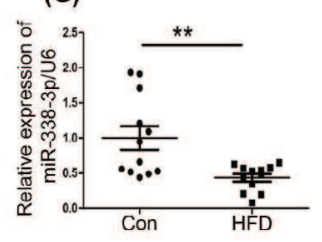

(H)

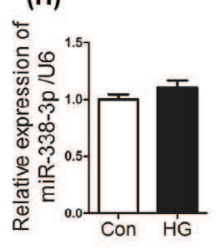

(F)

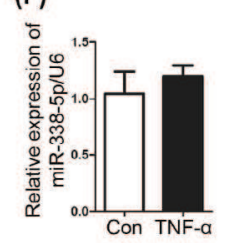

(I)

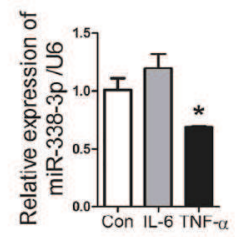

(G). Treatment with TNF- $\alpha$, but not glucose and IL-6, led to reduced miR-338-3p expression (H and I). Data are the means \pm SEM. $\mathrm{N}=3$ independent experiments or $\mathrm{N}=5$ mice. ${ }^{*} \mathrm{p}<0.05$; ${ }^{* *} \mathrm{p}<0.01$ versus control.

\section{Hepatic over-expression of miR-338-3p reverses TNF- $\alpha$-induced insulin resistance}

To confirm the effect of miR-338-3p on TNF- $\alpha$-induced insulin resistance, miR-338-3p was up-regulated in the livers of TNF- $\alpha$-treated C57BL/6J mice after tail vein injection of adenoviral vector expressing miR-338-3p mimic (Ad-338m). Seven days after the adenoviral vector injection, the hepatic miR-338-3p level was increased (Fig. 2A), accompanied by an elevated glycogen level (Fig. 2B) and the activation of the AKT/GSK3 $\beta$ pathway (Fig. 2C). Importantly, glucose tolerance tests (GTT) and insulin tolerance tests (ITT) indicated improvements in glucose tolerance and insulin sensitivity upon miR-338-3p over-expression in the TNF- $\alpha$-treated C57BL/6J mice (Fig. 2D, E). As shown in Fig. 2F, the body weight of the mice did not change. However, the liver weight and liver index were reduced in the Ad$338 \mathrm{~m}$-injected mice. Liver index is defined as the ratio of liver weight and body weight. Consistently, the over-expression of miR-338-3p improved glycogenesis and the activation of the AKT/GSK3 $\beta$ pathway in HEP1- 6 cells (Fig. 2G, H and I). Up-regulation of miR-338-3p in the HEP1- 6 cells treated with TNF- $\alpha$ could rescue TNF- $\alpha$-induced insulin resistance (Fig. 2J and $\mathrm{K}$ ). Taken together, these data suggested that miR-338-3p might play a distinct role in TNF- $\alpha$-induced insulin resistance.

\section{Hepatic inhibition of miR-338-3p leads to insulin resistance}

We further investigated the effect of miR-338-3p inhibition on hepatic insulin resistance. miR-338-3p was inhibited in the livers of C57BL/6J mice after tail vein injection of the adenoviral vector expressing miR-338-3p inhibitor (Ad-338i). Seven days after adenoviral vector injection, the hepatic miR-338-3p level was reduced (Fig. 3A), accompanied by a decrease in the glycogen level (Fig. 3B) and the activation of the AKT/GSK3 $\beta$ pathway (Fig. 3C). Importantly, glucose tolerance tests (GTT) and insulin tolerance tests (ITT) indicated elevated glucose tolerance upon miR-338-3p inhibition in the TNF- $\alpha$-treated C57BL/6J mice (Fig. 3D, E). As shown in Fig. 3F, the liver weight and liver index, but not body weight, were increased in the Ad-338i-injected mice. Consistently, the inhibition of miR-338-3p led to 


\section{Cellular Physiology Cell Physiol Biochem 2017;41:2419-2431 and Biochemistry \\ Dou et al: Mir-338-3p Regulate the PI3K/AKT Pathway}

Fig. 2. Hepatic over-expression of miR-338-3p reverses TNF- $\alpha$-induced insulin resistance. Increased miR-338$3 p$ level (A), glycogen level (B) and activation of the AKT/GSK3 $\beta$ pathway (C) in the livers of TNF- $\alpha$-treated C57BL/6J mice after tail vein injection of the adenoviral vector expression miR-338-3p mimic (Ad-338-3p m) for 7 days. Glucose tolerance tests (GTT) (D) and insulin tolerance tests (ITT) (E) upon miR-338-3p over-expression in the C57BL/6J mice treated with TNF- $\alpha$. The body weight, liver weight and liver index (F) in TNF$\alpha$-treated C57BL/6] mice after tail vein
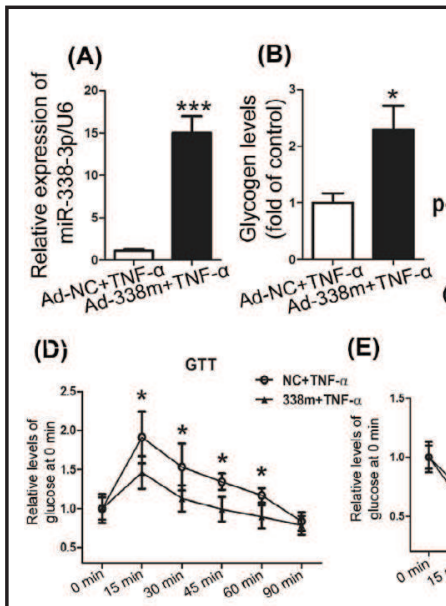

(E)
(C) Ad-NC+TNF- $a$ Ad-338m+TNF- $\alpha$

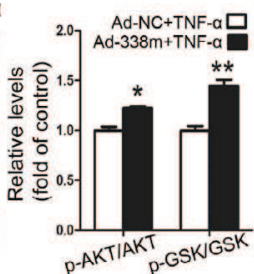

(F)

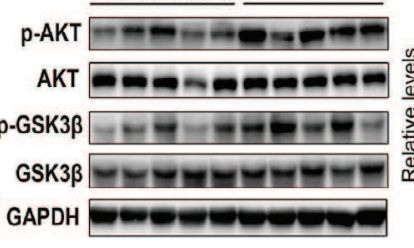

(F)

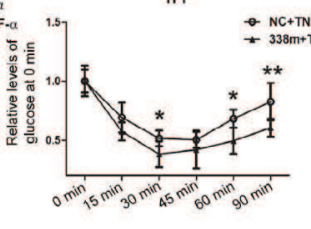

(H)

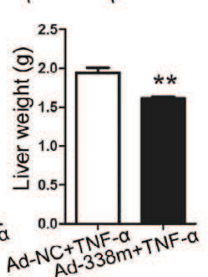

(G)
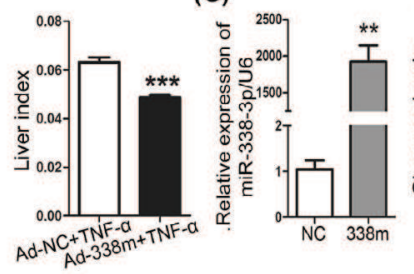

(I)
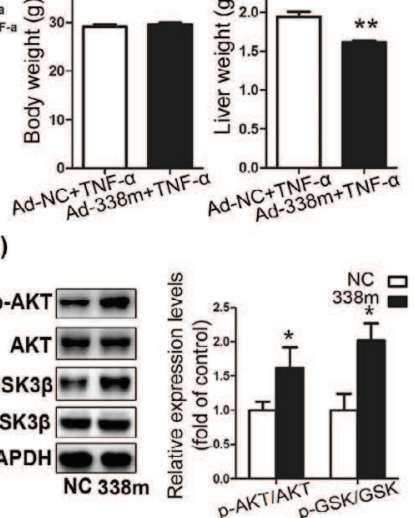

(J)

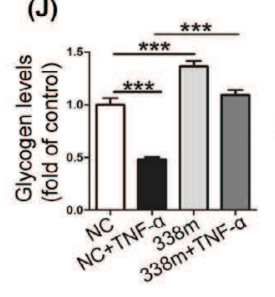

(K)
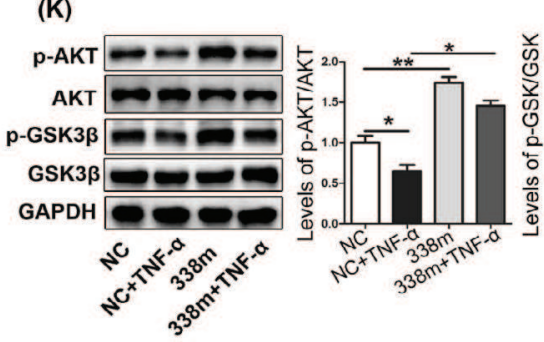

injection of Ad-338-3p m. Glycogenesis (G) and activation of the AKT/GSK3 $\beta$ pathway (H) in the HEP1-6 cells transfected with Ad-338-3p m. Glycogen content (I), activation of the AKT/GSK3 $\beta$ pathway (J) in the HEP1- 6 cells treated with $10 \mathrm{ng} / \mathrm{ml}$ TNF- $\alpha$ for $24 \mathrm{~h}$ followed by transfection with the miR-338-3p mimic for $48 \mathrm{~h}$. Data are the means \pm SEM. $N=3$ independent experiments or $N=5$ mice. ${ }^{*} \mathrm{p}<0.05 ;{ }^{* *} \mathrm{p}<0.01$ versus control.

impaired glycogenesis and reduced activation of the AKT/GSK3 $\beta$ pathway in the HEP1- 6 cells (Fig. 3G, H and I). Moreover, the down-regulation of miR-338-3p in HEP1-6 cells promoted TNF- $\alpha$-induced insulin resistance, as shown in Fig. 3J, K.

$P P 4 R 1$ is a direct target of $m i R-338-3 p$

The miRNA target prediction database TargetScan was used to analyse putative target genes of miR-338-3p. miR-338-3p has a binding site from 616-638 bp in the PP4R1 3'-UTR (Fig. 4A). To further verify PP4R1 as a target gene of miR-338-3p, a luciferase reporter vector containing a miR-338-3p binding site in the 3'-UTR of PP4R1 was constructed. As shown in Fig. 4B, the relative luciferase activity was significantly decreased by transfection with miR338-3p. The expression of PP4R1 was down-regulated in the HEP1-6 cells transfected with the miR-338-3p mimic (Fig. 4C). In contrast, the transfection of HEP1-6 cells with the miR338-3p inhibitor up-regulated the expression of PP4R1 (Fig. 4D). It has been reported that PP4R1 could improve the stability of the PP4 protein. In our previous study, we identified PP4 as a novel regulator in hepatic insulin resistance induced by TNF- $\alpha$. As shown in Fig. 4C, $\mathrm{D}$, the protein level of PP4 was also regulated by miR-338-3p. Moreover, the levels of PP4R1 and PP4 were increased in the livers of $\mathrm{db} / \mathrm{db}$ and TNF- $\alpha$-treated mice (Fig. 4E, F). These 


\section{Cellular Physiology Cell Physiol Biochem 2017;41:2419-2431 and Biochemistry POI: 10.1159/000475912 2017 () 2017 The Author(s). Published by S. Karger AG, Basel \\ Dou et al.: Mir-338-3p Regulate the PI3K/AKT Pathway}

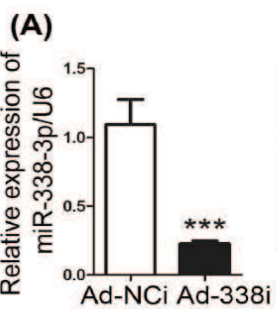

(D)

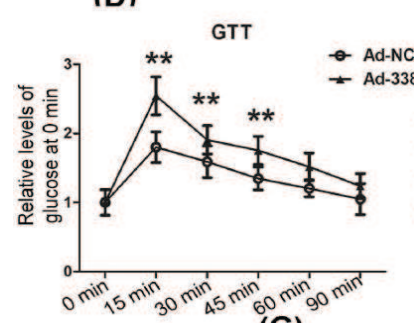

(G)
(B)

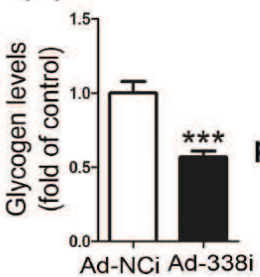

(E)
(C)

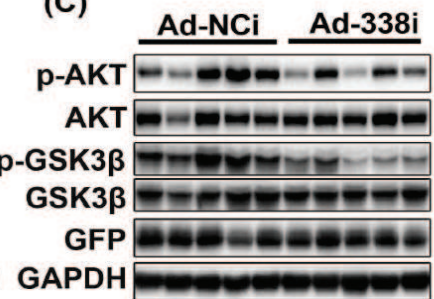

(F)

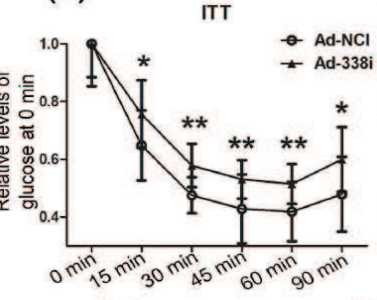

(H)
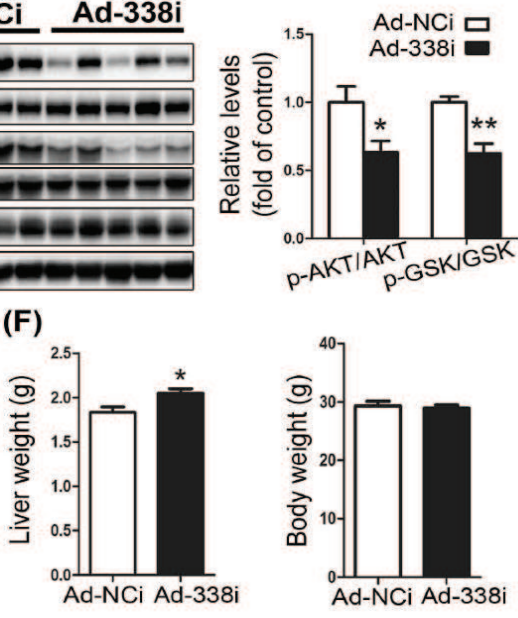

(I)
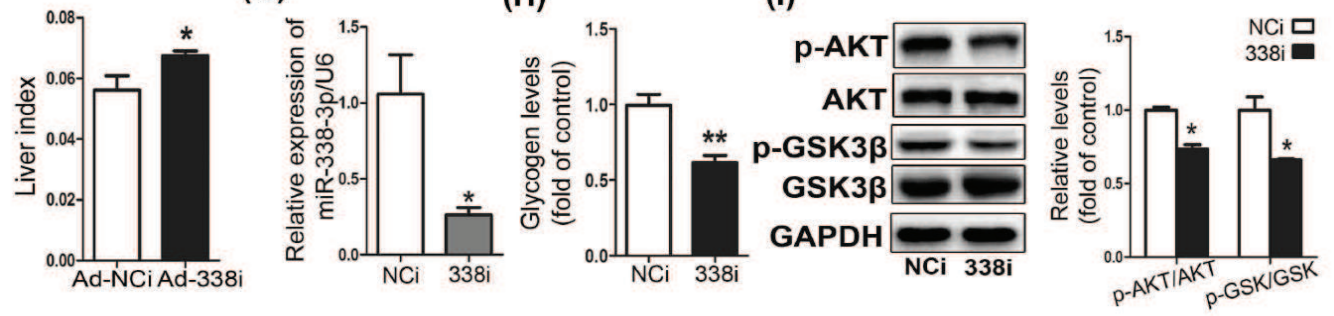

(J)

(K)
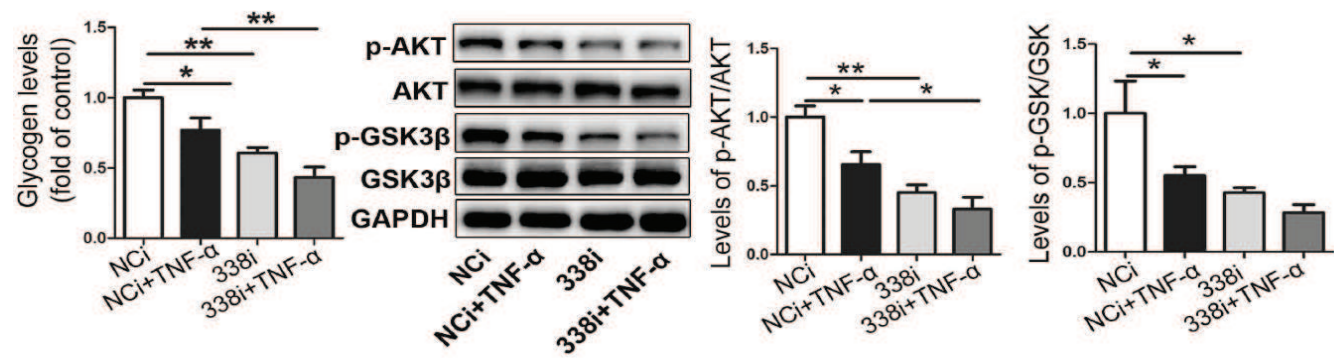

Fig. 3. Hepatic inhibition of miR-338-3p leads to insulin resistance. Reduced miR-338-3p expression (A), glycogen content (B), and activation of the AKT/GSK3 $\beta$ pathway (C) in the liver of C57BL/6J mice after tail vein injection of the adenoviral vector expressing miR-338-3p inhibitor (Ad-338 i) for 7 days. Glucose tolerance tests (GTT) (D) and insulin tolerance tests (ITT) (E) upon miR-338-3p inhibition in the C57BL/6J mice treated with TNF- $\alpha$. The body weight, liver weight and liver index (F) in the TNF- $\alpha$-treated C57BL/6J mice after tail vein injection of Ad-338-3p i. Glycogenesis (G) and activation of the AKT/GSK3 $\beta$ pathway $(H)$ in the HEP1- 6 cells transfected with Ad-338-3p i. Glycogen content (I) and activation of AKT/GSK3 $\beta$ pathway (J) in the HEP1- 6 cells treated with $10 \mathrm{ng} / \mathrm{ml} \mathrm{TNF-} \alpha$ for $24 \mathrm{~h}$ followed by transfection with the miR-338$3 p$ inhibitor for $48 \mathrm{~h}$. Data are the means \pm SEM. N=3 independent experiments or $\mathrm{N}=5$ mice. ${ }^{*} \mathrm{p}<0.05$; ${ }^{* *}$ $\mathrm{p}<0.01$ versus control.

data suggested that PP4R1 is a direct target of miR-338-3p and PP4R1 might be involved in the regulation of the insulin signalling pathway by PP4.

PP4R1 participates in miR-338-3p-mediated insulin resistance by regulating PP4

To determine the role of PP4R1 in miR-338-3p-mediated insulin resistance, two siRNAs (si-252, si-2410) targeting PP4R1 were transfected into HEP1-6 cells. As shown in Fig. 5A, 


\section{Cellular Physiology Cell Physiol Biochem 2017;41:2419-2431

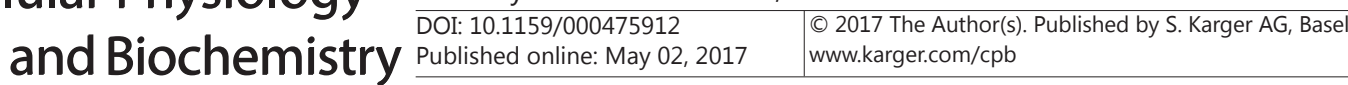 \\ Dou et al.: Mir-338-3p Regulate the PI3K/AKT Pathway}

Fig. 4. $P P 4 R 1$ is a direct target of miR338-3p. Binding site of miR-338-3p on the 3'-UTR of PPP4R1 (A), as analysed by the miRNA target prediction database TargetScan. Reduction in the luciferase activity (B) in the HEP1-6 cells transfected with the miR-338-3p mimic and the luciferase reporter vector containing the 3'-UTR of PPP4R1. Reduced PP4R1 and PP4 levels (C) in the HEP1-6 cells transfected with the miR-338-3p mimic. Elevated PP4R1 and PP4 levels (D) in the HEP1-6 cells transfected with the miR-338-3p inhibitor. Elevated PP4R1 and PP4 levels in the

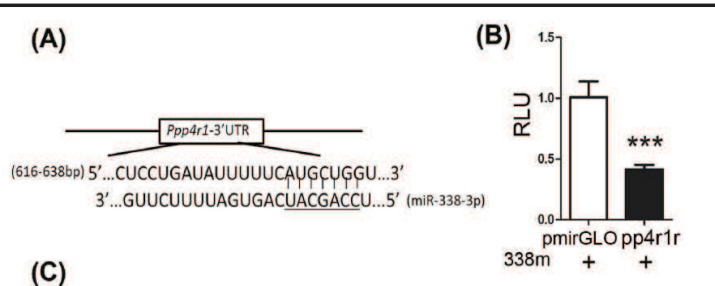

(C)
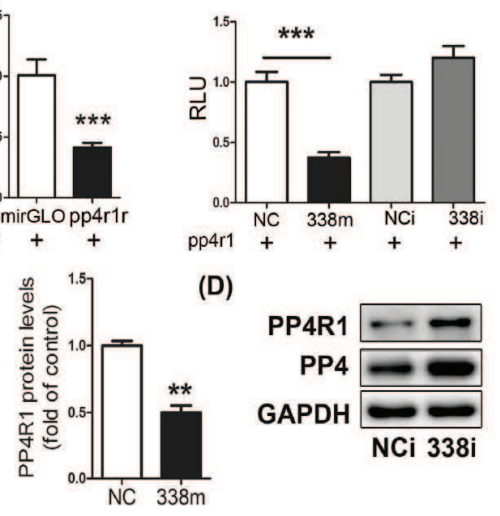

(D)
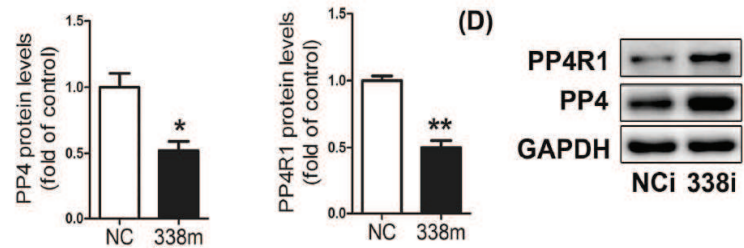

(E)
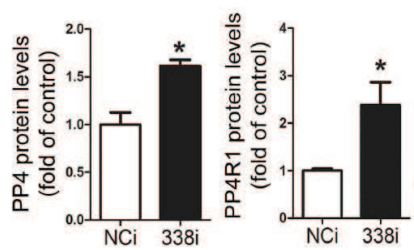

$\mathrm{db} / \mathrm{db}$
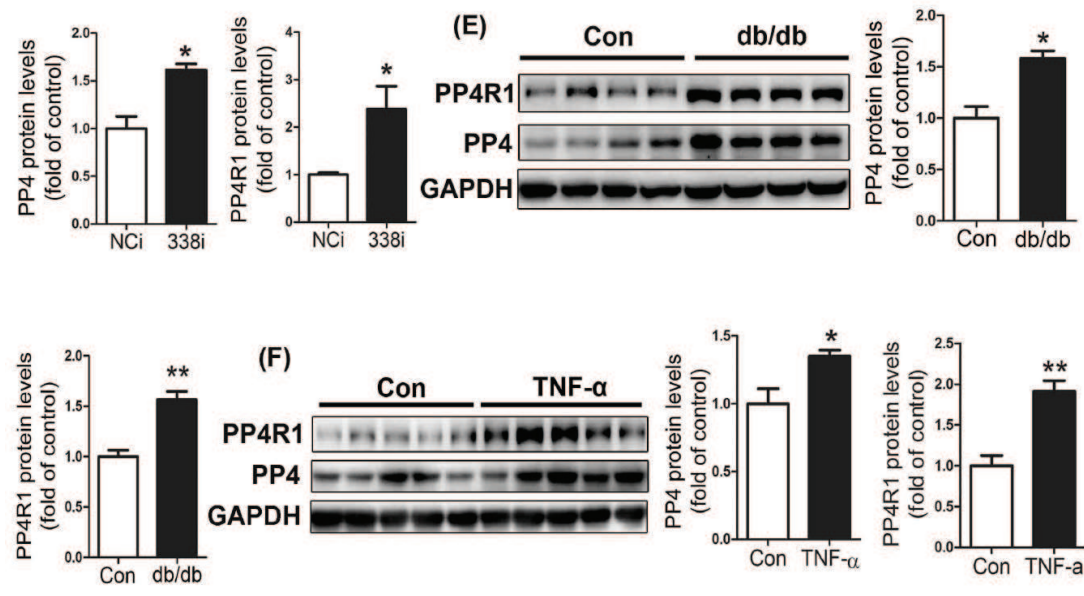

(F)
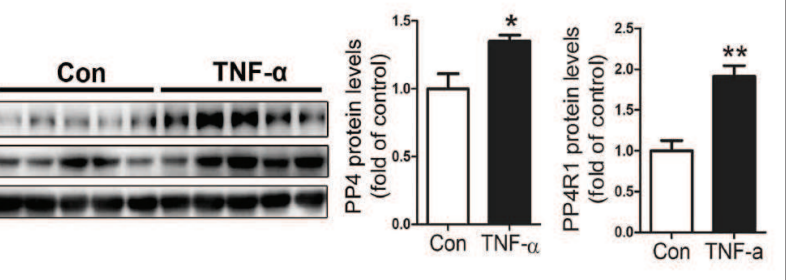

livers of $\mathrm{db} / \mathrm{db}$ mice $(\mathrm{E})$ and TNF- $\alpha$-treated mice $(\mathrm{F})$. Data are the means $\pm \mathrm{SEM}$. $\mathrm{N}=3$ independent experiments or $\mathrm{N}=5$ mice. $^{*} \mathrm{p}<0.05$; $^{* *} \mathrm{p}<0.01$; ${ }^{* * *} \mathrm{p}<0.001$ versus control.

both si-252 and si-2410 could successfully inhibit the protein expression of PP4R1. Downregulation of PP4R1 rescued the effect of TNF- $\alpha$ on the generation of glycogen, expression of PP4 and PP4R1, and activation of the AKT/GSK3 $\beta$ pathway (Fig. 5B, C). Next, we investigated the effect of PP4R1 on miR-338-3p-mediated insulin resistance. For this purpose, si-2410 and miR-338-3p inhibitor were co-transfected into HEP1-6 cells. Down-regulation of PP4R1 reversed the effect of the miR-338-3p inhibitor on insulin resistance (Fig. 5D, E). These results indicated that miR-338-3p could mediate the activation of the insulin signalling pathway by regulating PP4R1.

Based on the fact that PP4R1 is one of the regulatory subunits of PP4 [27] and that PP4 has been reported as a critical regulator in TNF- $\alpha$-induced hepatic insulin resistance [28], we presumed that PP4R1 might participate in miR-338-3p-mediated insulin resistance through PP4. To gain further insight into the role of PP4 in miR-338-3p-mediated insulin resistance, we co-transfected the adenovirus expressing PP4 shRNA (Ad-PP4i) and Ad-338i into HEP1-6 cells. The results showed that the knock-down of PP4 restored the miR-338$3 p$ inhibitor-induced insulin resistance (Fig. 5F, G). Furthermore, the over-expression of PP4 could rescued the effect of si-PP4R1 on the activation of the insulin signalling pathway and glycogenesis (Fig. 5H, I). These data revealed that PP4R1 participated in miR-338-3pmediated insulin resistance in hepatocytes by regulating PP4.

$H N F-4 \alpha$ is the transcriptional regulator of miRNA-338-3p

miR-338-3p is generated from an intron of the gene coding for apoptosis-associated tyrosine kinase (AATK). It has been predicted by the Gene Regulation database that HNF$4 \alpha$ is a transcriptional regulator of AATK (Fig. 6A). The results of the ChIP assay showed 


\section{Cellular Physiology Cell Physiol Biochem 2017;41:2419-2431

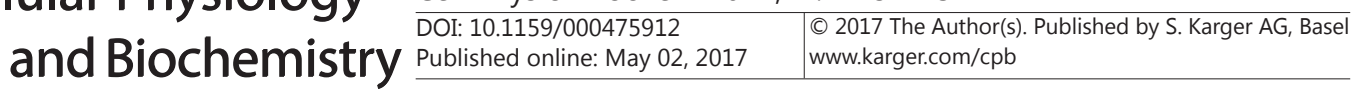

Fig. 5. PP4R1 participates in miR-338-3pmediated insulin resistance by regulating PP4. Protein levels of PP4R1 and PP4 (A) in the HEP16 cells transfected with siRNA targeting PP4R1. Glycogen content (B) and activation of the AKT/GSK3 $\beta$ pathway (C) in the TNF- $\alpha$-treated HEP1-6 cells transfected with siRNA targeting PP4R1. Glycogen content (D) and activation of the AKT/GSK3 $\beta$ pathway (E) in the HEP1-6 cells co-transfected with siRNA targeting PP4R1 and miR-338-3p inhibitor. Glycogen content (F) and activation of the AKT/GSK3 $\beta$ pathway (G) in the HEP1-6 cells co-transfected with siRNA targeting PP4 and miR-338-3p inhibitor. Glycogen content (H) and activation of the AKT/GSK3 $\beta$ pathway (I) in the HEP1-6 cells cotransfected with PP4 and siRNA targeting PP4R1. Data are the means \pm SEM. $\mathrm{N}=3$ independent experiments. ${ }^{*} \mathrm{p}<0.05$; ** $\mathrm{p}<0.01$ versus control.
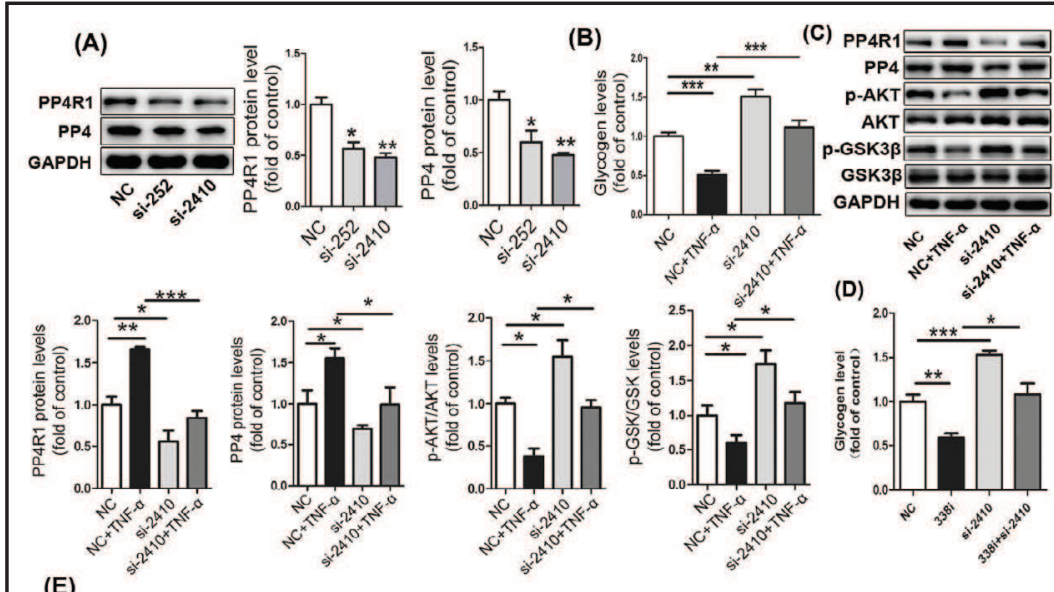

(E)
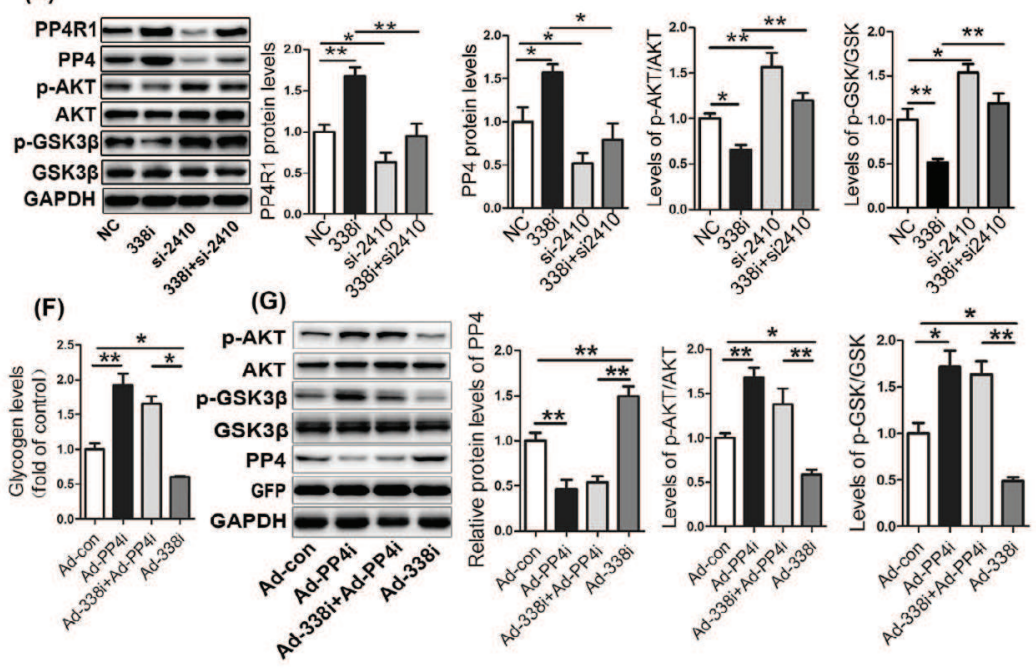

(H)

$$
\text { (I) }
$$
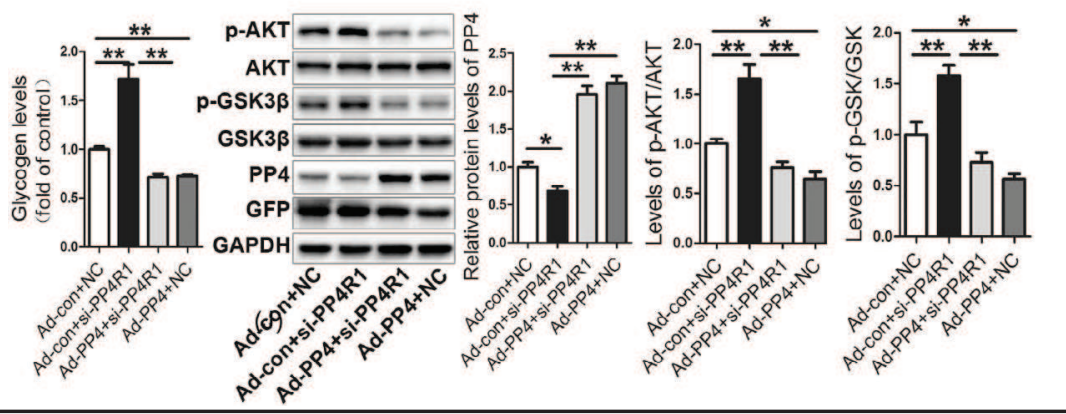

that HNF-4 $\alpha$ could directly bind to the promoter of AATK (Fig. 6B). Knock-down of HNF-4 $\alpha$ significantly reduced the expression of AATK and miRNA-338-3p (Fig. 6C). In addition, the protein level of HNF-4 $\alpha$ was decreased in the livers of the $\mathrm{db} / \mathrm{db}$ and TNF- $\alpha$-treated mice (Fig. $6 \mathrm{D}, \mathrm{E})$. Moreover, the inhibition of HNF-4 $\alpha$ impaired the activation of the insulin signalling pathway and reduced glycogenesis in HEP1-6 cells (Fig. 6F, G).

\section{Discussion}

In the present study, we identified the critical role of miR-338-3p in regulating hepatic insulin resistance. First, we found that miR-338-3p was significantly down-regulated in the livers of the $\mathrm{db} / \mathrm{db}$, HFD-fed and TNF- $\alpha$-treated C57BL/6J mice, as well as in mouse HEP1- 


\section{Cellular Physiology Cell Physiol Biochem 2017;41:2419-2431 \begin{tabular}{l|l|l} 
aOI: 10.1159/000475912 & $\begin{array}{l}\text { @ 2017 The Author(s). Published by S. Karger AG, Basel } \\
\text { www.karger.com/cpb }\end{array}$ \\
\hline
\end{tabular} \\ Dou et al.: Mir-338-3p Regulate the PI3K/AKT Pathway}

Fig. 6. HNF- $4 \alpha$ is the transcriptional regulator of miRNA-338-3p. HNF- $4 \alpha$ as a transcriptional regulator of apoptosis-associated tyrosine kinase (AATK) (A), as predicted by the Gene Regulation database. ChIP assay showing that HNF- $4 \alpha$ could directly bind to the promoter of AATK (B). Reduced expression of AATK and miRNA-338-3p (C) in the HEP1-6 cells transfected with siRNA targeting HNF- $4 \alpha$. Reduced expression of HNF- $4 \alpha$ in the livers of $d b /$ $\mathrm{db}$ (D) and TNF- $\alpha$-treated C57BL/6J mice (E). Glycogen content $(\mathrm{F})$ and activation of the AKT/GSK pathway (G) in the HEP1-6 cells transfected with siRNA targeting HNF- $4 \alpha$ (si-951 and si-1436). Data are the means \pm SEM. $\mathrm{N}=3$ independent experiments or $\mathrm{N}=5$ mice. ${ }^{*} \mathrm{p}<0.05$; ** $\mathrm{p}<0.01$ versus control.
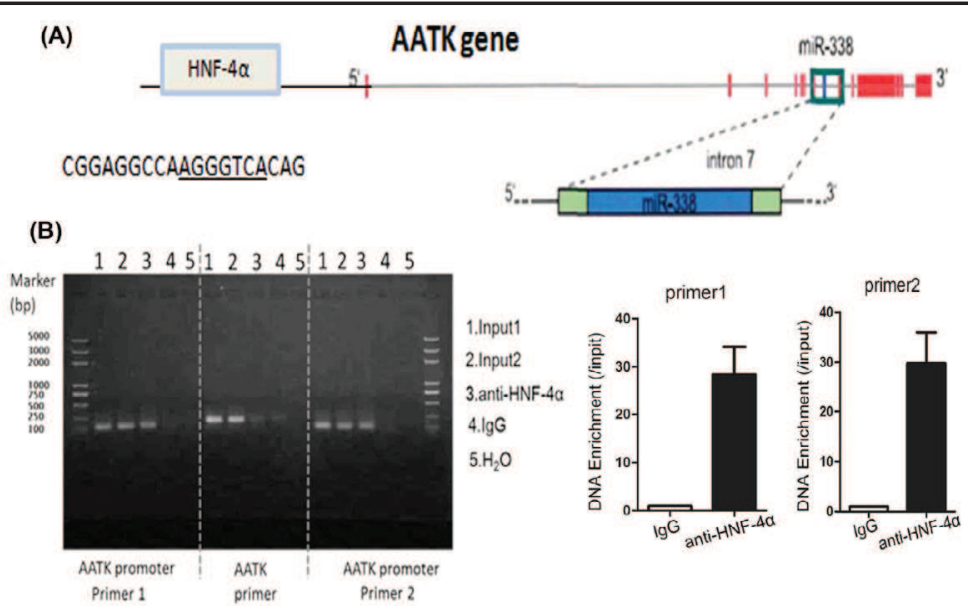

(C)
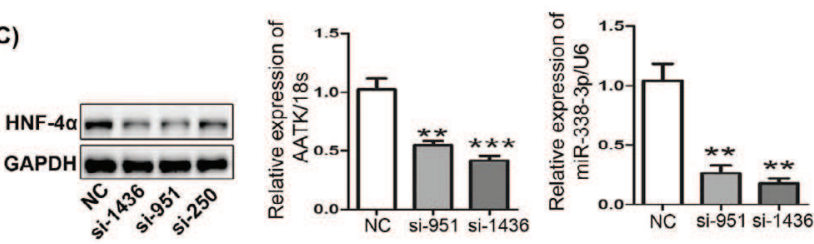

(D)

$$
\text { (E) }
$$

(F)

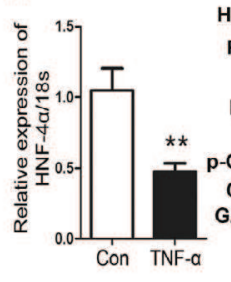

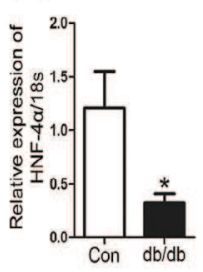

HNF-4a $-(-\cdots$ PP4R1 PP4 $-2=-10=$ P-AKT P-AKT - - АKT $-2-\pi-2$ -GSK3 $\beta$ GSK3 $--0-0$ GAPDH $\overline{\text { si-951 NC si-1436 }}$
(G)

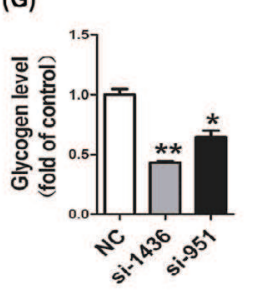

6 hepatocytes treated with TNF- $\alpha$. Second, our in vivo and in vitro results suggested that TNF- $\alpha$-induced hepatic insulin resistance was rescued by the over-expression of miR338-3p, while the hepatic inhibition of miR338-3p led to insulin resistance. Third, we verified PP4R1 as a direct target of miR-338$3 p$ that mediates the activation of insulin resistance by regulating PP4. Finally, we identified HNF- $4 \alpha$ as the transcriptional regulator of miRNA-338-3p.

The miR-338-3p gene is located within intron 8 of the apoptosis-associated tyrosine kinase (AATK) gene and produces two mature microRNAs, miR-338-3p and miR$338-5 p$. It has been reported that the level

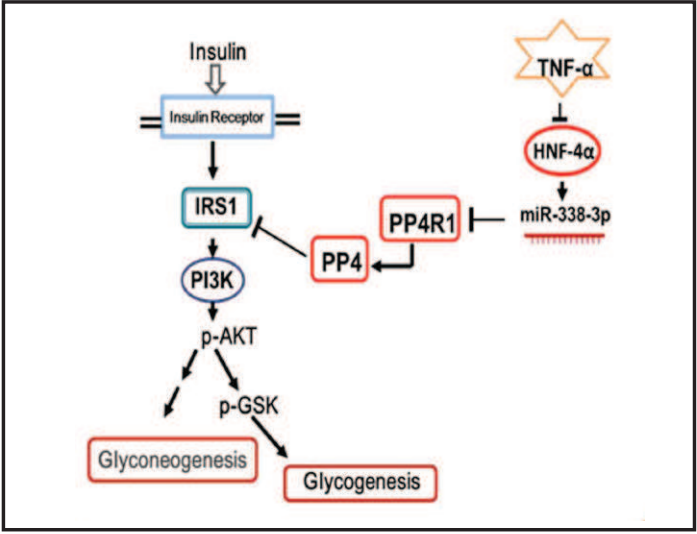

Fig. 7. A working model where miR-338-3p mediates TNF- $\alpha$-induced hepatic insulin resistance by targeting PP4R1 to regulate PP4 expression of miR-338-3p is reduced in the pancreatic islets from rodent models displaying insulin resistance and compensatory $\beta$-cell mass expansion, including diet-induced obese mice and $\mathrm{db} / \mathrm{db}$ mice. Our data showed that the expression of miR-338-3p, but not miR-338-5p, was down-regulated in the livers of TNF$\alpha$-treated mice (Fig. 1F). Importantly, the expression of miR-338-3p was also significantly reduced in human NAFLD patients (Fig. 1G). Because the physiology of the $\mathrm{db} / \mathrm{db}$ mice is complex and accompanied by other factors, such as elevated levels of serum glucose, IL-6 and TNF- $\alpha$, it is difficult to determine the contribution of TNF- $\alpha$ in the down-regulation of 


\section{Cellular Physiology Cell Physiol Biochem 2017;41:2419-2431 and Biochemistry Publisned online: 1vay 02, $2017 \quad \begin{aligned} & \text { D 2017 The Authors. } \\ & \text { www.karger.com/cpb }\end{aligned}$ \\ Dou et al.: Mir-338-3p Regulate the PI3K/AKT Pathway}

miR-338-3p. Therefore, mouse HEP1-6 cells were treated with $33.3 \mathrm{mM}$ glucose for $48 \mathrm{~h}$, $10 \mathrm{ng} / \mathrm{ml} \mathrm{IL-} 6$ for $24 \mathrm{~h}$ and $10 \mathrm{ng} / \mathrm{ml} \mathrm{TNF}-\alpha$ for $24 \mathrm{~h}$ to induce insulin resistance. As shown in Fig. $1 \mathrm{H}$ and I, the treatment with TNF- $\alpha$, but not glucose or IL-6, led to the reduction in miR-338-3p expression. Moreover, we found that miR-338-3p level was also decreased in the livers of C57BL/6J mice injected with $15 \mu \mathrm{g} / \mathrm{ml}$ TNF- $\alpha$ by pumps. In addition, hepatic over-expression of miR-338-3p rescued the TNF- $\alpha$-induced insulin resistance, whereas the inhibition of miR-338-3p induced insulin resistance.

We further identified PP4R1 as a target of miR-338-3p. Based on the database analysis, the luciferase reporter assay revealed that miR-338-3p could directly bind to the 3'-UTR of PP4R1. Over-expression of miR-338-3p inhibited the protein level of PP4R1, while inhibition of miR-338-3p elevated the expression of PP4R1. PP4R1 is one of the regulatory subunits of PP4 [27], and PP4 has been reported as a critical regulator in TNF- $\alpha$-induced hepatic insulin resistance [27]. PP4 is a protein complex comprised of a catalytic subunit PP4C, which belongs to the PP2A family, and other regulatory subunits [29]. PP4 has been reported to be involved in multiple cellular processes such as microtubule organization, apoptosis regulation and DNA damage repair [27, 30-32]. It has been reported that PP4 could regulated TNF- $\alpha$ signalling by activating c-Jun N-terminal kinase (JNK)[33]. Moreover, our previous study had proposed a direct interaction between PP4 and IRS-1. PP4 impaired the insulin signalling pathway by increasing the phosphorylation of IRS-1 and JNK [28].The PP4CPP4R1 complex played a role in the dephosphorylation and regulation of HDAC3 [34]. It was demonstrated that PP4R1 formed part of a distinct PP4 holoenzyme and targeted TRAF2 and TRAF6 to mediate NF- $\mathrm{KB}$ signalling [35]. In the present study, we found that PP4R1 participated in the miR-338-3p-mediated insulin resistance by regulating PP4. Previously, we found that PP4 promoted hepatic lipogenesis through the dephosphorylating acetylCoA carboxylase 1 on serine 79[36]. In addition to glucose metabolism, our unpublished data also suggest that miR-338-3p might play a role in hepatic lipogenesis. It was reported that HNF-4 $\alpha$ played a vital role in regulating hepatic differentiation $[37,38]$. Several studies demonstrated the major effect of HNF-4a in the control of genes involved in glucose and fat metabolism [39]. The result of the bioinformatics analysis showed that there was a binding site of HNF-4 $\alpha$ at the promoter of the miR-338-3p host gene AATK. ChIP assay verified that HNF- $4 \alpha$ could directly bind to the promoter of AATK. Moreover, our results indicated that the protein level of HNF- $4 \alpha$ was decreased in the livers of the $\mathrm{db} / \mathrm{db}$ and TNF- $\alpha$-treated mice. Knock-down of HNF- $4 \alpha$ significantly reduced the expression of AATK and miRNA-338$3 p$. In addition, inhibition of HNF-4 $\alpha$ impaired the insulin signalling pathway and glycogen synthesis in HEP1- 6 cells. Taken together, these data suggested that HNF- $4 \alpha$ was involved in hepatic glucose metabolism by regulating miRNA-338-3p.

In summary, as shown in Fig. 7, our studies provide novel insight into the critical role and molecular mechanism by which miR-338-3p is involved in TNF- $\alpha$-induced hepatic insulin resistance. miR-338-3p might mediate TNF- $\alpha$-induced hepatic insulin resistance by targeting PP4R1 to regulate PP4 expression.

\section{Acknowledgments}

This work was supported by grants from the National Basic Research Program (973 program) of China (2014CB910503), grants (81570789 and 81600618) from the National Natural Science Foundation of China, and grants (BJ-2015-106) from Beijing Hospital.

\section{Disclosure Statement}

The authors declare no conflict of interest. 


\section{Cellular Physiology Cell Physiol Biochem 2017;41:2419-2431 \begin{tabular}{c|c|c|c|}
\hline DOI: 10.1159/000475912 & (c) 2017 The Author(s). Published by S. Karger AG, Basel
\end{tabular} and Biochemistry Published online: May 02, 2017 www.karger.com/cpb}

Dou et al.: Mir-338-3p Regulate the PI3K/AKT Pathway

\section{References}

1 Yach D, Brownell KD: Epidemiologic andeconomic consequences of the global epidemics of obesity and diabetes. Nat Med 2006;12:62-66.

72 Li J, Wei X, Xie Q, Hoa Pham TT, Wei J, He P, Jiao Y, Xu X, Giang Nguyen TH, Wen Q, Huang R: Protective Effects of 2-Dodecyl-6-Methoxycyclohexa-2,5-Diene- 1,4-Dione Isolated from Averrhoa Carambola L. (Oxalidaceae) Roots on High-Fat Diet-Induced Obesity and Insulin Resistance in Mice. Cell Physiol Biochem 2016;40:993-1004.

-3 Sartorius T, Drescher A, Panse M, Lastovicka P, Peter A, Weigert C, Kostenis E, Ullrich S, Häring HU: Mice Lacking Free Fatty Acid Receptor 1 (GPR40/FFAR1) are Protected Against Conjugated Linoleic AcidInduced Fatty Liver but Develop Inflammation and Insulin Resistance in the Brain. Cell Physiol Biochem 2015;35:2272-2284.

4 Leclercq IA, Da Silva Morais A, Schroyen B, Van Hul N, Geerts A: Insulin resistance in hepatocytes and sinusoidal liver cells: mechanisms and consequences. J Hepatol 2007;47:142-156.

-5 Nolasco EL, Zanoni FL, Nunes FP, Ferreira SS, Freitas LA, Silva MC, Martins JO: Insulin Modulates Liver Function in a Type I Diabetes Rat Model. Cell Physiol Biochem 2015;36:1467-1479.

-6 Pradhan AD, Manson JE, Rifai N, Buring JE, Ridker PM: C-reactive protein, interleukin 6, and risk of developing type 2 diabetes mellitus. Jama 2001;286:327-334.

7 Gleeson M, Bishop NC, Stensel DJ, Lindley MR, Mastana SS, Nimmo MA: The anti-inflammatory effects of exercise: mechanisms and implications for the prevention and treatment of disease. Nat Rev Immunol 2011;11:607-615.

-8 Gillies N, Pendharkar SA, Asrani VM, Mathew J, Windsor JA, Petrov MS: Interleukin-6 is associated with chronic hyperglycemia and insulin resistance in patients after acute pancreatitis. Pancreatology 2016;16:748-755.

-9 Khodabandehloo H, Gorgani-Firuzjaee S, Panahi G, Meshkani R: Molecular and cellular mechanisms linking inflammation to insulin resistance and beta-cell dysfunction. Transl Res 2016;167:228-256.

10 Palacios-Ortega S, Varela-Guruceaga M, Algarabel M, Ignacio Milagro F, Alfredo Martínez J, de Miguel C: Effect of TNF-Alpha on Caveolin-1 Expression and Insulin Signaling During Adipocyte Differentiation and in Mature Adipocytes. Cell Physiol Biochem 2015;36:1499-1516.

-11 Carthew RW: Gene regulation by microRNAs. Curr Opin Genet Dev 2006;16:203-208.

12 Ambros V: The functions of animal microRNAs. Nature 2004;431:350-355.

-13 Farr RJ, Joglekar MV, Hardikar AA: Circulating microRNAs in Diabetes Progression: Discovery, Validation, and Research Translation. EXS 2015;106:215-244.

- 14 Ciccacci C, Di Fusco D, Cacciotti L, Morganti R, D’Amato C, Greco C, Rufini S, Novelli G, Sangiuolo F, Spallone V, Borgiani P: MicroRNA genetic variations: association with type 2 diabetes. Acta Diabetol 2013;50:867872.

15 Poy MN, Eliasson L, Krutzfeldt J, Kuwajima S, Ma X, Macdonald PE, Pfeffer S, Tuschl T, Rajewsky N, Rorsman P, Stoffel M: A pancreatic islet-specific microRNA regulates insulin secretion. Nature 2004;432:226-230.

-16 Trajkovski M, Hausser J, Soutschek J, Bhat B, Akin A, Zavolan M, Heim MH, Stoffel M: MicroRNAs 103 and 107 regulate insulin sensitivity. Nature 2011;474:649-653.

17 Pandey AK, Verma G, Vig S, Srivastava S, Srivastava AK, Datta M: MiR-29a levels are elevated in the db/ $\mathrm{db}$ mice liver and its overexpression leads to attenuation of insulin action on PEPCK gene expression in HepG2 cells. Mol Cell Endocrinol 2011;332:125-133.

-18 Zhou B, Li C, Qi W, Zhang Y, Zhang F, Wu J, Hu Y, Wu D, Liu Y, Yan T: Downregulation of miR-181a upregulates sirtuin-1 (SIRT1) and improves hepatic insulin sensitivity. Diabetologia 2012;55:2032-2043.

19 Dou L, Zhao T, Wang L, Huang X, Jiao J, Gao D, Zhang H, Shen T, Man Y, Wang S, Li J: miR-200s contribute to interleukin-6 (IL-6)-induced insulin resistance in hepatocytes. J Biol Chem 2013; 288:22596-22606.

20 Dou L, Wang S, Sui X, Meng X, Shen T, Huang X, Guo J, Fang W, Man Y, Xi J, Li J: MiR-301a mediates the effect of IL- 6 on the AKT/GSK pathway and hepatic glycogenesis by regulating PTEN expression. Cell Physiol Biochem 2015;35: 1413-1424.

21 Dou L, Meng X, Sui X, Wang S, Shen T, Huang X, Guo J, Fang W, Man Y, Xi J, Li J: MiR-19a regulates PTEN expression to mediate glycogen synthesis in hepatocytes. Sci Rep 2015;5:11602. 


\section{Cellular Physiology Cell Physiol Biochem 2017;41:2419-2431

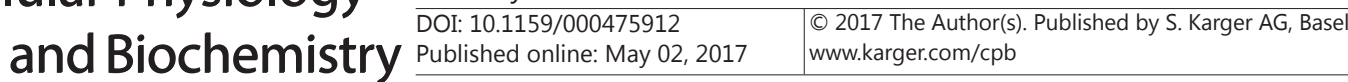

Dou et al.: Mir-338-3p Regulate the PI3K/AKT Pathway

22 Jacovetti C, Jimenez V, Ayuso E, Laybutt R, Peyot ML, Prentki M, Bosch F, Regazzi R: Contribution of Intronic miR-338-3p and Its Hosting Gene AATK to Compensatory beta-Cell Mass Expansion. Mol Endocrinol 2015;29:693-702.

-23 Aschrafi A, Kar AN, Natera-Naranjo O, MacGibeny MA, Gioio AE, Kaplan BB: MicroRNA-338 regulates the axonal expression of multiple nuclear-encoded mitochondrial mRNAs encoding subunits of the oxidative phosphorylation machinery. Cell Mol Life Sci 2012;69:4017-4027.

24 Li P, Chen X, Su L, Li C, Zhi Q Yu B, Sheng H, Wang J, Feng R, Cai Q: Epigenetic silencing of miR-338-3p contributes to tumorigenicity in gastric cancer by targeting SSX2IP. PLoS One 2013;8:e66782.

25 Xu H, Zhao L, Fang Q, Sun J, Zhang S, Zhan C, Liu S, Zhang Y: MiR-338-3p inhibits hepatocarcinoma cells and sensitizes these cells to sorafenib by targeting hypoxia-induced factor $1 \alpha$. PloS one 2014;9:e115565.

-26 Kos A, Loohuis NF, Wieczorek ML, Glennon JC, Martens GJ, Kolk SM, Schrafi A: A Potential Regulatory Role for Intronic microRNA-338-3p for Its Host Gene Encoding Apoptosis-Associated Tyrosine Kinase. PLoS One 2012;7:e31022.

27 Cohen PT, Philp A, Vazquez-Martin C: Protein phosphatase 4--from obscurity to vital functions. FEBS Lett 2005;579:3278-3286.

-28 Zhao H, Huang X, Jiao J, Zhang H, Liu J, Qin W, Meng X, Shen T, Lin Y, Chu J, Li J: Protein phosphatase 4 (PP4) functions as a critical regulator in tumor necrosis factor (TNF)- $\alpha$-induced hepatic insulin resistance. Sci Rep 2015;5:e18093

29 Li X, Liang L, Huang L, Ma X, Li D, Cai S: High expression of protein phosphatase 4 is associated with the aggressive malignant behavior of colorectal carcinoma. Mol Cancer 2015;14:95.

30 Toyo-oka K, Mori D, Yano Y, Shiota M, Iwao H, Goto H, Inagaki M, Hiraiwa N, Muramatsu M, Wynshaw-Boris A, Yoshiki A, Hirotsune S: Protein phosphatase 4 catalytic subunit regulates Cdk1 activity and microtubule organization via NDEL1 dephosphorylation. J Cell Biol 2008;180:1133-1147.

-31 Vazquez-Martin C, Rouse J, Cohen PT: Characterization of the role of a trimeric protein phosphatase complex in recovery from cisplatin-induced versus noncrosslinking DNA damage. FEBS J 2008;275:42114221.

- 32 Mourtada-Maarabouni M, Williams GT: Protein phosphatase 4 regulates apoptosis, proliferation and mutation rate of human cells. Biochim Biophys Acta 2008;1783:1490-1502.

- 33 Zhou G, Mihindukulasuriya KA, MacCorkle-Chosnek RA, Van Hooser A, Hu MC, Brinkley BR, Tan T H: Protein phosphatase 4 is involved in tumor necrosis factor-alpha-induced activation of c-Jun N-terminal kinase. J Biol Chem 2002; 277:6391-6398.

34 Zhang X, Ozawa Y, Lee H, Wen YD, Tan TH, Wadzinski BE, Seto E: Histone deacetylase 3 (HDAC3) activity is regulated by interaction with protein serine/threonine phosphatase 4. Genes Dev 2005;19:827-839.

- 35 Hadweh P, Habelhah H, Kieff E, Mosialos G, Hatzivassiliou E: The PP4R1 subunit of protein phosphatase PP4 targets TRAF2 and TRAF6 to mediate inhibition of NF-kappaB activation. Cell Signal 2014;26:27302737.

36 Meng X, Li M, Guo J, Tang W, Wang S, Man Y, Huang X, Li J: Protein phosphatase 4 promotes hepatic lipogenesis through dephosphorylating acetyl CoA carboxylase 1 on serine 79. Mol Med Rep 2014;10:1959-1963.

- 37 Odom DT, Zizlsperger N, Gordon DB, Bell GW, Rinaldi NJ, Murray HL, Volkert TL, Schreiber J, Rolfe PA, Gifford DK, Fraenkel E, Bell GI, Young A: Control of pancreas and liver gene expression by HNF transcription factors. Science 2004;303:1378-1381.

38 Chen ML, Lee KD, Huang HC, Tsai YL, Wu YC, Kuo TM, Hu CP, Chang C: HNF-4 $\alpha$ determines hepatic differentiation of human mesenchymal stem cells from bone marrow. World J Gastroenterol 2010;16:50925103.

-39 Klapper M, Böhme M, Nitz I, Döring F: The human intestinal fatty acid binding protein (hFABP2) gene is regulated by HNF-4a. Biochem Biophys Res Commun 2007;356:147-152. 